\title{
Peripheral tissue homing receptor control of naïve, effector, and memory CD8T cell localization in lymphoid and non-lymphoid tissues
}

\section{Colin Brinkman, J. David Peske and Victor Henry Engelhard*}

Department of Microbiology, Immunology, and Cancer Biology, Carter Immunology Center, University of Virginia School of Medicine, Charlottesville, VA, USA

\section{Edited by:}

Susan Swain, University of

Massachusetts Medical School, USA

Reviewed by:

Marcelo B. Sztein, University of Maryland School of Medicine, USA

David Hildeman, Cincinnati Children's Hospital, USA

\section{*Correspondence}

Victor Henry Engelhard, Department of Microbiology, Immunology, and

Cancer Biology, Carter Immunology

Center, University of Virginia School of

Medicine, P. O. Box 801386, MR6

Building, Room 3523, Charlottesville,

VA 22908, USA

e-mail:vhe@virginia.edu
T cell activation induces homing receptors that bind ligands on peripheral tissue vasculature, programing movement to sites of infection and injury. There are three major types of CD8 effectorT cells based on homing receptor expression, which arise in distinct lymphoid organs. Recent publications indicate that naïve, effector, and memory T cell migration is more complex than once thought; while many effectors enter peripheral tissues, some reenter lymph nodes (LN), and contain central memory precursors. LN re-entry can depend on $\mathrm{CD} 62 \mathrm{~L}$ or peripheral tissue homing receptors. Memory T cells in LN tend to express the same homing receptors as their forebears, but often are CD62Lneg. Homing receptors also control CD8 T cell tumor entry. Tumor vasculature has low levels of many peripheral tissue homing receptor ligands, but portions of it resemble high endothelial venules $(\mathrm{HEV})$, enabling naïve T cell entry, activation, and subsequent effector activity. This vasculature is associated with positive prognoses in humans, suggesting it may sustain ongoing anti-tumor responses. These findings reveal new roles for homing receptors expressed by naïve, effector, and memory CD8T cells in controlling entry into lymphoid and non-lymphoid tissues.

Keywords: $\mathrm{T}$ cell trafficking, $\mathrm{T}$ cell memory, $\mathrm{T}$ cell heterogeneity, tumor infiltrating lymphocytes, $\mathrm{T}$ cell migration, $T$ cell recirculation, memory $\mathrm{T}$ cell trafficking, effector $\mathrm{T}$ cell migration

\section{INTRODUCTION}

$\mathrm{T}$ cells are capable of assuming an impressive array of functional phenotypes. Much of this variation can be traced to differences in the place, context, or time since antigen exposure. The best recognized example of effector cell heterogeneity is the subset specialization of $\mathrm{CD} 4 \mathrm{~T}$ cells based on cytokine secretion profiles (Th1, Th2, Th17, and Treg) (1). However, another example of functional specialization is the programing of CD4 and CD8 T cells to express different selectins, integrins, and chemokine receptors, which enable homing to different sites in the body. The particular constellation of such "homing receptors" expressed by individual cells depends on antigen encounter, and on microenvironmental characteristics of the secondary lymphoid organs (SLO). Just as importantly, however, the ability of such $\mathrm{T}$ cells to enter any particular tissue is dependent on which homing receptor ligands are expressed on the associated vasculature. Here we review the range of trafficking programs expressed by naïve, effector, and memory CD8 $\mathrm{T}$ cells, and the extent to which they dictate $\mathrm{T}$ cell entry into SLO and peripheral tissues, particularly tumors.

\section{T CELL HOMING RECEPTOR HETEROGENEITY DURING THE PRIMARY RESPONSE}

$\mathrm{T}$ cell entry into tissues from the bloodstream is controlled by a multistep adhesion cascade involving interactions between homing receptors on the surface of $\mathrm{T}$ cells with their respective ligands on vasculature (2). Naïve T cells enter lymph nodes ( $\mathrm{LN}$ ) via L-selectin (CD62L) and chemokine receptor CCR7, which bind ligands on high endothelial venules (HEV) (3). Upon differentiation into effectors, CD62L and CCR7 are downregulated, and new homing receptors upregulated (Tables 1 and 2). Integrin $\alpha 4 \beta 7$ and CCR9 support homing to gut-associated tissue, the vasculature of which expresses the ligands MAdCAM-1 and CCL25 (4-7). In contrast, the ligands for E-selectin and P-selectin (ESL and PSL respectively) enable homing to skin, where inflamed vasculature expresses these selectins $(8-11)$. While CCR4 is reported to be necessary for CD4 T cell entry into inflamed skin (12), other work has shown that $\mathrm{CD} 4$ and $\mathrm{CD} 8 \mathrm{~T}$ cell infiltration does not require CCR4 and instead may depend on CCR10 (13), or CXCR3 and CCR5 (14). Much less is known about which homing receptors enable $\mathrm{T}$ cell entry into other tissues. $\alpha 4 \beta 1$ integrin, which binds VCAM-1, has been implicated in T cell infiltration into the brain $(15,16)$, lung $(17)$, and bronchus-associated lymphoid tissue (18, 19). While activated CD8 T cells express many different chemokine receptors (Table 2), there is remarkably little direct information about the expression of their ligands in different tissues, which is essential in understanding the role they might play.

Expression of some homing receptors on effector $\mathrm{T}$ cells is determined by their activation site. CD4 $\mathrm{T}$ cells activated in cutaneous LN upregulate PSL, while those activated in mucosal LN upregulate $\alpha 4 \beta 7$ (20). This is mirrored in vitro using dendritic cells (DC) to activate CD8 T cells. DC from skin-draining LN induce ESL and PSL, while DC from mesenteric LN or Peyer's patches induce $\alpha 4 \beta 7$ and CCR9 (21-23) based in part on their synthesis and presentation of retinoic acid $(24,25)$. However, $\alpha 4 \beta 7$ can 
Table 1 | Adhesion molecules expressed by murine CD8 T cells.

\begin{tabular}{|c|c|c|c|c|c|}
\hline $\begin{array}{l}\text { Adhesion } \\
\text { molecule }\end{array}$ & Expression & $\begin{array}{l}\text { Primary ligand/ } \\
\text { binding partner }\end{array}$ & $\begin{array}{l}\text { Constitutive ligand } \\
\text { expression }\end{array}$ & $\begin{array}{l}\text { Inducible ligand } \\
\text { expression }\end{array}$ & $\begin{array}{l}\text { Ligand expression in } \\
\text { tumor vasculature }\end{array}$ \\
\hline$\alpha 4 \beta 1$ & $\begin{array}{l}\text { Low on naïve, upregulated } \\
\text { upon activation }\end{array}$ & VCAM-1 & $\begin{array}{l}\text { Bone marrow, low } \\
\text { levels in } \mathrm{HEV}\end{array}$ & $\begin{array}{l}\text { Inflamed brain, lung (BALT), } \\
\text { liver }\end{array}$ & Sometimes detected \\
\hline$\alpha 4 \beta 7$ & $\begin{array}{l}\text { Reported low on naïve, } \\
\text { upregulated upon activation }\end{array}$ & MAdCAM-1 & $\begin{array}{l}\text { Mesenteric LN, } \\
\text { Peyer's patch HEV, } \\
\text { small intestine } \\
\text { postcapillary venules }\end{array}$ & $\begin{array}{l}\text { Increased by inflammation, } \\
\text { including in some sites } \\
\text { beyond gut mucosa }\end{array}$ & Not known \\
\hline $\begin{array}{l}\alpha \mathrm{E} \beta 7 \\
(\mathrm{CD} 103)\end{array}$ & $\begin{array}{l}\text { None or low on naïve, } \\
\text { upregulated on T cell subsets } \\
\text { at epithelial surfaces }\end{array}$ & E-cadherin & Epithelia & $\mathrm{N} / \mathrm{A}$ & $\begin{array}{l}\text { Often downregulated } \\
\text { during epithelial to } \\
\text { mesenchymal transition }\end{array}$ \\
\hline $\begin{array}{l}\alpha L \beta 2 \\
(L F A-1)\end{array}$ & $\begin{array}{l}\text { Present on naïve and } \\
\text { activated T cells }\end{array}$ & ICAM-1 & Postcapillary venules & Increased by inflammation & Frequently detected \\
\hline CD44 & $\begin{array}{l}\text { Low on naïve T cells, } \\
\text { upregulated upon activation }\end{array}$ & Hyaluronan & $\begin{array}{l}\text { Connective, } \\
\text { endothelial, neural } \\
\text { tissue }\end{array}$ & Increased by tissue injury & $\begin{array}{l}\text { Accumulates in many } \\
\text { tumors }\end{array}$ \\
\hline ESL & $\begin{array}{l}\text { Absent on naïve T cells, } \\
\text { upregulated upon activation }\end{array}$ & E-selectin (CD62E) & $\begin{array}{l}\text { Low levels in dermal } \\
\text { postcapillary venules }\end{array}$ & $\begin{array}{l}\text { Inflamed dermal postcapillary } \\
\text { venules, other inflamed } \\
\text { postcapillary venules }\end{array}$ & $\begin{array}{l}\text { Unclear, but blockade } \\
\text { can reduce } T \text { cell } \\
\text { infiltration }\end{array}$ \\
\hline $\begin{array}{l}\text { L-selectin } \\
\text { (CD62L) }\end{array}$ & $\begin{array}{l}\text { Naïve T, memory subsets, } \\
\text { downregulated upon } \\
\text { activation }\end{array}$ & $\begin{array}{l}\text { Peripheral node } \\
\text { addressin (PNAd) }\end{array}$ & $\begin{array}{l}\text { LN HEV endothelial } \\
\text { cells }\end{array}$ & $\begin{array}{l}\text { Inflamed non-HEV blood } \\
\text { endothelium }\end{array}$ & $\begin{array}{l}\text { Subset of vessels in } \\
\text { some tumors }\end{array}$ \\
\hline PSL & $\begin{array}{l}\text { Low on naïve } T \text { cells, } \\
\text { upregulated upon activation }\end{array}$ & P-selectin (CD62P) & $\begin{array}{l}\text { Low levels in dermal } \\
\text { postcapillary venules }\end{array}$ & $\begin{array}{l}\text { Inflamed dermal postcapillary } \\
\text { venules, other inflamed } \\
\text { postcapillary venules, } \\
\text { activated platelets }\end{array}$ & $\begin{array}{l}\text { Unclear, but blockade } \\
\text { can reduce } T \text { cell } \\
\text { infiltration }\end{array}$ \\
\hline
\end{tabular}

be also induced without RA $(23,24,26)$. Similarly, induction of CCR10 on human T cells is promoted by DC processing of Vitamin D3 to $1,25(\mathrm{OH})_{2} \mathrm{D}_{3}$, but this effect is less pronounced for mouse T cells (27). IL-2 and IL-12 are potent inducers of PSL expression on $\mathrm{T}$ cells in vitro, but dispensable in vivo $(28,29)$. In vitro studies have shown that induction of CCR 5 on activated mouse CD4 and CD8 T cells requires IL-12 (30), while CXCR3 induction requires IFN- $\gamma$ (31). Even less is known about the factors that control the induction of other homing receptors.

Recently, we examined homing receptor expression during CD8 $\mathrm{T}$ cell activation in different LN and spleen. Intravenous (IV) immunization with bone marrow derived DC activates T cells in mediastinal LN and spleen, most of which upregulate $\alpha 4 \beta 1$ integrin and PSL but not ESL or $\alpha 4 \beta 7$ (32-34). Intraperitoneal (IP) immunization activates T cells in mesenteric and mediastinal LN, which express $\alpha 4 \beta 7$ integrin and PSL $(32,33)$. Finally, subcutaneous (SC) immunization activates $\mathrm{T}$ cells in skin-draining LN, most of which express ESL and PSL, and some of which also express $\alpha 4 \beta 1$ (33). This work defines three major CD8 T cell effector populations that differentially express $\alpha 4 \beta 7, \alpha 4 \beta 1$, or ESL. Each of these molecules mediates the initial capture and tethering interaction of $\mathrm{T}$ cells with the vasculature (35-37), providing a basis for tissue selectivity, while $\alpha 4 \beta 1$ can also mediate firm adhesion
(38). In contrast, expression of chemokine receptors shows little variation with activation site. Most activated CD8 $\mathrm{T}$ cells in all LN express CXCR3, and smaller subsets co-express CCR3, CCR4, CCR5, CCR6, and CCR9 (33). Only CCR9 expression varies significantly, with the largest fraction present on cells activated in mesenteric LN.

These results identify a previously unrecognized subset of effectors that uniformly expresses $\alpha 4 \beta 1$, but little ESL or $\alpha 4 \beta 7$, which is generated in the mediastinal LN and spleen by IV immunization. Other work has shown that IV immunization induces $\mathrm{T}$ cells that are incapable of mediating contact hypersensitivity (39), entering the gut (32), or controlling SC melanomas (40). Our work suggests that these observations reflect a homing receptor profile that does not enable $\mathrm{T}$ cell entry into skin or gut tissue. Conversely, as induction of $\alpha 4 \beta 1$ is weak after SC immunization, $\mathrm{T}$ cells generated by this route may only poorly infiltrate sites that require this integrin for entry. The layered coexpression of multiple chemokine receptors by $\mathrm{CD} 8 \mathrm{~T}$ cells contrasts with a study that associated expression of CXCR3, CCR4, and CXCR5 with functionally distinct CD4 T cell subsets (41), but is consistent with another study showing coordinate expression of CCR4, CCR6, and CCR10 by human CD4 T cells (42). Thus, individual CD8 T cells may be more multipotential in their homing specificity than CD4 T cells. In any 
Table 2 | Chemokine receptors expressed by murine T cells.

\begin{tabular}{|c|c|c|c|c|c|}
\hline Receptor & T cell receptor expression & Ligand & $\begin{array}{l}\text { Constitutive ligand } \\
\text { expression }\end{array}$ & Inducible ligand expression & $\begin{array}{l}\text { Ligand expression in } \\
\text { tumor vasculature }\end{array}$ \\
\hline CXCR3 & Activated Th1, activated CD8 & $\begin{array}{l}\text { CXCL11 (ITAC) } \\
\text { CXCL10 (IP-10) } \\
\text { CXCL9 (MIG) }\end{array}$ & & Induced by Th1 inflammation & Not known \\
\hline CXCR4 & $\begin{array}{l}\text { Low to absent on naïve, } \\
\text { upregulated after activation } \\
\text { CD8 > CD4 }\end{array}$ & CXCL12 (SDF-1) & $\begin{array}{l}\text { Bone marrow } \\
\text { endothelium, thymus, } \\
\text { lung, lymphoid organs }\end{array}$ & & Not known \\
\hline CXCR6 & Th1 activated CD8 T cells & CXCL16 & & Induced by Th1 inflammation & Induced by radiation \\
\hline CCR1 & Memory T cells & $\begin{array}{l}\text { CCL3 (MIP-1a) } \\
\text { CCL5 (RANTES) } \\
\text { CCL7 (MARC) } \\
\text { CCL16 (LCC-1) }\end{array}$ & & Induced by inflammation & Not known \\
\hline CCR3 & $\begin{array}{l}\text { Th2 }>\text { Th1 activated CD8 } T \\
\text { cells }\end{array}$ & $\begin{array}{l}\text { CCL5 (RANTES) } \\
\text { CCL7 (MARC) } \\
\text { CCL8 (MCP-2) }\end{array}$ & & Induced by inflammation & Not known \\
\hline CCR4 & $\begin{array}{l}\text { Th2 in vitro activated } \mathrm{CD} 8 \mathrm{~T} \\
\text { cells }\end{array}$ & $\begin{array}{l}\text { CCL17 (TARC) } \\
\text { CCL22 (MDC) }\end{array}$ & & $\begin{array}{l}\text { Induced by inflammation, } \\
\text { particularly in dermis }\end{array}$ & Not known \\
\hline CCR5 & Th1 activated CD8 T cells & $\begin{array}{l}\text { CCL5 (RANTES) } \\
\text { CCL4 (MIP) } \\
\text { CCL3 (MIP) }\end{array}$ & & Induced by inflammation & Not known \\
\hline CCR8 & $\begin{array}{l}\text { Subset of Th2 memory, } \\
\text { negligible on CD8T cells }\end{array}$ & CCL1 (TCA-3) & & Induced by Th2 inflammation & Not known \\
\hline CCR9 & $\begin{array}{l}\text { Subsets of naïve and } \\
\text { activated CD4 and CD8T cells }\end{array}$ & CCL25 (TECK) & Small intestine & & Not known \\
\hline CCR10 & $\begin{array}{l}\text { Skin-homing activated CD4 } \\
\text { and CD8T cells CD4 > CD8 }\end{array}$ & CCL27 & Skin & $\begin{array}{l}\text { Upregulated in epidermis } \\
\text { after inflammation }\end{array}$ & Not known \\
\hline
\end{tabular}

case, infiltration is ultimately dependent on expression patterns of the chemokines themselves, which remains somewhat poorly characterized (43). The multipotential chemokine-sensing capability of CD8 T cells may also provide a failsafe mechanism to ensure the entry of these effector cells into peripheral sites occupied by pathogens or tumors.

\section{CD8 T CELL REDISTRIBUTION AMONG LN}

While some activated CD8 T cells leave SLO bound for inflamed peripheral tissues, others traffic to antigen-free $\operatorname{LN}(34,44)$. These LN-redistributed cells resemble fully differentiated effectors by dividing extensively and secreting IFN $\gamma$ (34). However, at least some were central memory precursors (34). LN redistribution depends in part upon residual expression of CD62L by some of these differentiated CD8 T cells (34). $\alpha 4 \beta 7$ integrin has long been known to enable activated T cell entry into mesenteric LN (34, 45). Recently, we found that activated CD8 T cells also redistribute into antigen-free LN using $\alpha 4 \beta 1$ and ESL (46); $\alpha 4 \beta 1$ enables entry into all LN, and ESL mediates selective entry into skin-draining LN. This results in differential accumulation of ESL ${ }^{+}$and $\alpha 4 \beta 1^{+}$ $\mathrm{T}$ cells in skin-draining vs. non-skin-draining LN after SC immunization or transfer of SC-primed effectors into naïve hosts. Others 
have shown that CD62Lneg T cells can enter inflamed, but not resting, LN using CXCR3 (47) or PSL (48). Thus, homing receptors normally associated with trafficking to peripheral non-lymphoid tissues also control the distribution of activated $\mathrm{T}$ cells among different lymphoid tissues, even in the absence of inflammation.

\section{HOMING RECEPTOR EXPRESSION AND REGIONAL LOCALIZATION OF T CELL MEMORY}

Like effector cells, memory $\mathrm{T}$ cells are made up of distinct subsets. Central memory $\mathrm{T}$ cells $\left(\mathrm{T}_{\mathrm{CM}}\right)$ are defined as $\mathrm{CD}_{2} \mathrm{~L}^{+} \mathrm{CCR} 7^{+}$ and are found primarily in $\mathrm{LN}$, while effector memory cells ( $\mathrm{T}_{\mathrm{EM}}$ ) are defined as CD62LnegCCR7neg and are found predominantly in peripheral tissue, spleen, and blood (49-52). Resident $\mathrm{T}_{\mathrm{EM}}$ $\left(\mathrm{rT}_{\mathrm{EM}}\right)(52,53)$ are retained permanently at epithelial surfaces, likely through expression of the E-cadherin receptor $\alpha \mathrm{E} \beta 7$, which is detected using anti-CD103 specific for the $\alpha \mathrm{E}$ subunit (54-56). Migratory $\mathrm{T}_{\mathrm{EM}}\left(\mathrm{mT}_{\mathrm{EM}}\right)$ are CD103neg and recirculate $(54,57$, 58). $\mathrm{T}_{\mathrm{EM}}$ can express homing receptors associated with entry into peripheral tissue $(54,59-62)$.

Expression of CD62L and CCR7 and LN residence have been used somewhat interchangeably to define central memory cells $\left(\mathrm{T}_{\mathrm{CM}}\right)(49,63)$. However, many memory cells in $\mathrm{LN}$ do not express one or both of these molecules $(34,64,65)$. It has been proposed that $\mathrm{mT}_{\mathrm{EM}}$ cells exit peripheral tissue through the afferent lymphatics $(66,67)$, and utilization of this pathway by CD4 T cells has recently been directly demonstrated (68). Because the afferent lymphatics drain into $\mathrm{LN}, \mathrm{mT}_{\mathrm{EM}}$ could be a component of what is generally thought of as $\mathrm{T}_{\mathrm{CM}}$ despite their lack of CD62L expression. We found that CD62Lneg memory CD8 T cells in LN continue to express ESL, PSL, and $\alpha 4 \beta 1$ in patterns that mirror those of primary effectors (46). The distribution of these memory cells also reflects that of $\mathrm{LN}$-redistributing effectors, with $\mathrm{ESL}^{+}$ memory CD8 $\mathrm{T}$ cells tending to reside in skin-draining $\mathrm{LN}$, and ESLneg $\alpha 4 \beta 1^{+} \mathrm{T}$ cells tending to reside in non-skin-draining $\mathrm{LN}$ and spleen. Importantly, SC immunization, which induces $\mathrm{ESL}^{+}$ memory $\mathrm{T}$ cells, results in enhanced memory $\mathrm{T}$ cell residence in skin-draining $\mathrm{LN}$ and augmented recall responses to skin immunization challenge (46). Thus, the CD8 T cells we have identified share properties of both $\mathrm{T}_{\mathrm{CM}}$ and $\mathrm{T}_{\mathrm{EM}}$. They seem analogous to a recently described population of recirculating $\mathrm{ESL}^{+}$memory CD4 $\mathrm{T}$ cells in skin and LN that do not express CD62L (68).

Interestingly, we found that these CD62Lneg LN-resident CD8 memory $\mathrm{T}$ cells can be reprogramed to express new peripheral tissue homing receptors, with minimal loss of those previously expressed (46). Thus, we have defined cells with enhanced representation in skin-draining $\mathrm{LN}$, which expand upon rechallenge in vivo, and are plastic enough to be reprogramed to express new homing receptors. This is perhaps the best of both worlds in terms of host protection: enhanced regional memory as well as a systemic component that can be reprogramed. Thus T cell memory is comprised not only of cells that permanently reside in non-lymphoid tissue, and cells that almost exclusively recirculate among SLO, but also cells that recirculate between tissue and LN. These latter cells may include both classically defined $\mathrm{mT}_{\mathrm{EM}}$ as well as cells that also have characteristics of $\mathrm{T}_{\mathrm{CM}}$. CD103 is useful for distinguishing migratory and resident memory in peripheral tissues, and CD62L is useful for defining classical TCM. However, we lack phenotypic markers to distinguish LN-resident CD62Lneg subpopulations, and they currently must be studied by examining functional phenotype and migration. Vaccination strategies must consider the patterns of homing receptors induced by different immunization routes. These results also suggest that appropriate prime-boost regimens might be able to generate protective memory with multipotential homing capability.

\section{CD8 T CELL HOMING TO TUMORS}

While we have a good understanding of control of CD8 T cell infiltration into LN, skin, and gut, the requirements for entry into other tissues are poorly defined. Of particular interest is infiltration into tumors. Several studies have demonstrated that the presence of a CD8 T cell infiltrate in tumors is associated with a positive prognosis in human cancer patients (69-72). A panoply of homing receptors have been implicated in $\mathrm{T}$ cell infiltration in various tumor models, including LFA- $1, \alpha 4 \beta 1$, CD44, ESL/PSL, CXCR3, CCR2, CCR5 ((73-79), our unpublished observations). However, seemingly conflicting roles have been reported for LFA-1 ligand ICAM-1 $(73,74)$. In addition, chemokine CCL5 has been correlated with both positive and poor prognosis (80, 81). This may reflect differences in ligand expression in different tumor types, locations, or differential recruitment of additional cell populations. An important factor limiting T cell entry is the minimal expression of homing receptor ligands, including ICAM1, E-selectin, and CXCR3 ligands on tumor vasculature. (82-84). Endothelin B receptor, CD73, and vascular endothelial growth factor (VEGF) have been shown to limit ligand expression $(73,85,86)$. This is consistent with the overall poor infiltration of adoptively transferred effector T cells in murine and clinical studies (87-90). Conversely, inflammatory stimuli and radiation have been shown to enhance CD8 T cell entry through upregulation of homing receptor ligands $(79,83,91)$ Thus, one approach to improve cancer immunotherapy is to identify and manipulate the expression of homing receptors and vascular ligands to enhance infiltration of CD8 effectors into tumors.

Although naïve $\mathrm{T}$ cells are generally excluded from peripheral tissues, we have found that they infiltrate and are activated in tumors of multiple tissue origins growing in the lungs, SC space, or peritoneal cavity (92). Naïve T cells infiltrate tumors by interacting with tumor associated vasculature that resembles that of LN HEV by expressing PNAd and CCL21, the ligands for CD62L and CCR7, respectively (Peske et al., manuscript submitted). While $\mathrm{PNAd}^{+}$vessels are normally found only in LN, chronic inflammation induces their development in many peripheral organs, often in the context of accumulations of hematopoietic and stromal cells that organize into structures termed tertiary lymphoid organs (TLO) (93-95). PNAd $^{+}$vessels have also recently been identified in several human tumors, although it was not shown whether they were associated with TLO (96). Other studies have identified TLO in human tumors associated with CCL21 expression (97-99). PNAd expression on HEVs in LN and TLO is primarily controlled by signals through the lymphotoxin-beta receptor (LTßR) (94, 100-105). In contrast, we found that PNAd expression in tumors does not require LT $\beta R$ signaling (Peske et al., manuscript submitted). Instead, effector lymphocytes induced the development of LN-like vasculature in part via secretion of IFN $\gamma$, which 
enhanced CCL21 expression. Thus, novel pathways control the development of HEV-like tumor vasculature. Importantly, HEV density or presence of TLO in human tumors correlates with positive prognosis $(96,97)$. The work of our lab and others suggests this is due to the recruitment of naïve T cells and subsequent generation of anti-tumor immune responses directly in the tumor (92, 106). Therefore, inducing HEV development in tumors may be a valuable therapeutic intervention.

\section{CONCLUSION}

$\mathrm{T}$ cell homing to inflamed peripheral tissues is controlled by expression of homing receptors induced by activation that vary according to the route of immunization. Our and others' work has built upon this understanding by illuminating surprising new roles for homing receptors expressed by naive, effector, and memory CD8 T cells in controlling their entry into both lymphoid tissues

\section{REFERENCES}

1. O'Shea JJ, Paul WE. Mechanisms underlying lineage commitment and plasticity of helper CD4+ T cells. Science (2010) 327:1098-102. doi:10.1126/ science. 1178334

2. Ley K, Laudanna C, Cybulsky MI, Nourshargh S. Getting to the site of inflammation: the leukocyte adhesion cascade updated. Nat Rev Immunol (2007) 7:678-89. doi:10. 1038/nri2156

3. Girard J-P, Moussion C, Förster R. HEVs, lymphatics and homeostatic immune cell trafficking in lymph nodes. Nat Rev Immunol (2012) 12:762-73. doi:10.1038/ nri3298

4. Hamann A, Andrew DP, JablonskiWestrich D, Holzmann B, Butcher EC. Role of alpha 4-integrins in lymphocyte homing to mucosal tissues in vivo. J Immunol (1994) 152:3282-93.

5. Stenstad H, Ericsson A, JohanssonLindbom B, Svensson M, Marsal J, Mack M, et al. Gut-associated lymphoid tissue-primed CD4+ $\mathrm{T}$ cells display CCR9-dependent and -independent homing to the small intestine. Blood (2006) 107:3447-54. doi:10.1182/blood2005-07-2860

6. Johansson-Lindbom B, Svensson M, Wurbel MA, Malissen B, Marquez G, Agace W. Selective generation of gut tropic $\mathrm{T}$ cells in gut-associated lymphoid tissue (GALT): requirement for GALT dendritic cells and adjuvant. J Exp Med (2003) 198:963-9. doi:10. 1084/jem.20031244

7. Kunkel EJ, Campbell JJ, Haraldsen G, Pan J, Boisvert J, Roberts AI, et al. Lymphocyte CC chemokine receptor 9 and epithelial thymus-expressed chemokine
(TECK) expression distinguish the small intestinal immune comtissue-specific chemokines as an organizing principle in regional immunity. J Exp Med (2000) 192:761-8. doi:10.1084/jem.192.5. 761

8. Berg EL, Yoshino T, Rott LS, Robinson MK, Warnock RA, Kishimoto TK, et al. The cutaneous lymphocyte antigen is a skin lymphocyte homing receptor for the vascular lectin endothelial cell-leukocyte adhesion molecule 1. J Exp Med (1991) 174:1461-6. doi:10.1084/ jem.174.6.1461

9. Vachino G, Chang XJ, Veldman GM, Kumar R, Sako D, Fouser LA, et al. P-selectin glycoprotein ligand-1 is the major counterreceptor for P-selectin on stimulated $\mathrm{T}$ cells and is widely distributed in non-functional form on many lymphocytic cells. J Biol Chem (1995) 270:21966-74. doi: 10.1074/jbc.270.37.21966

10. Erdmann I, Scheidegger EP, Koch FK, Heinzerling L, Odermatt B, Burg G, et al. Fucosyltransferase VII-deficient mice with defective E-, $\mathrm{P}-$, and L-selectin ligands show impaired CD4+ and CD8+ $\mathrm{T}$ cell migration into the skin, but normal extravasation into visceral organs. J Immunol (2002) 168:2139-46.

11. Hirata T, Furie BC, Furie B. P-, $\mathrm{E}-$, and L-selectin mediate migration of activated CD8+ T lymphocytes into inflamed skin. Jimmunol (2002) 169:4307-13.

12. Campbell JJ, O'Connell DJ, Wurbel M-A. Cutting edge: chemokine receptor CCR4 is necessary for antigen-driven cutaneous accumulation of $\mathrm{CD} 4 \mathrm{~T}$ cells under physiological partment: epithelial expression of

and tumors. It remains to be seen whether additional homing receptors are involved in trafficking to regional $\mathrm{LN}$, peripheral tissues other than skin and gut, and tumors in different body locations. A critical and still poorly described aspect is which homing receptor ligands are expressed by different tissues and tumors, and how this is positively and negatively regulated. It also is not clear how tissue-resident, lymphoid-resident, and migratory memory $\mathrm{T}$ cells interact to confer protection, or how to achieve an optimal mixture by vaccination. Finally, the notion of enhancing $\mathrm{T}$ cell immunity against localized pathogen infection or metastatic tumors growing in different locations by regional immunization to induce expression of appropriate homing receptors has yet to be incorporated into vaccine strategies. Nonetheless it is clear that $\mathrm{T}$ cell trafficking patterns are a source of both great specificity and flexibility waiting to be fully exploited for therapeutic benefit.

conditions. J Immunol (2007) 1950(178):3358-62.

13. Reiss Y, Proudfoot AE, Power CA, Campbell JJ, Butcher EC. CC chemokine receptor (CCR) 4 and the CCR10 ligand cutaneous $\mathrm{T}$ cell-attracting chemokine (CTACK) in lymphocyte trafficking to inflamed skin. $J$ Exp Med (2001) 194:1541-7. doi:10.1084/ jem.194.10.1541

14. Gregg RK, Nichols L, Chen Y, $\mathrm{Lu}$ B, Engelhard VH. Mechanisms of spatial and temporal development of autoimmune vitiligo in tyrosinasespecific TCR transgenic mice. $J$ Immunol (2010) 184:1909-17. doi:10.4049/jimmunol.0902778

15. Rott LS, Briskin MJ, Andrew DP, Berg EL, Butcher EC. A fundamental subdivision of circulating lymphocytes defined by adhesion to mucosal addressin cell adhesion molecule-1. Comparison with vascular cell adhesion molecule-1 and correlation with beta 7 integrins and memory differentiation. J Immunol (1996) 156:3727-36.

16. Calzascia T, Masson F, Di Berardino-Besson W, Contassot E, Wilmotte R, Urrand-Lions $\mathrm{M}$, et al. Homing phenotypes of tumor-specific CD8 $\mathrm{T}$ cells are predetermined at the tumor site by crosspresenting APCs. Immunity (2005) 22:175-84. doi:10.1016/j. immuni.2004.12.008

17. Kenyon NJ, Liu R, O’Roark EM, Huang W, Peng L, Lam KS. An alpha4betal integrin antagonist decreases airway inflammation in ovalbumin-exposed mice. Eur J Pharmacol (2009) 603:138-46. doi:10.1016/j.ejphar.2008.11.063

18. Kawamata N, Xu B, Nishijima H, Aoyama K, Kusumoto M, Takeuchi $\mathrm{T}$, et al. Expression of endothelia and lymphocyte adhesion molecules in bronchus-associated lymphoid tissue (BALT) in adult human lung. Respir Res (2009) 10:97. doi:10.1186/1465-9921-1097

19. Xu B, Wagner N, Pham LN, Magno V, Shan Z, Butcher EC, et al. Lymphocyte homing to bronchusassociated lymphoid tissue (BALT) is mediated by L-selectin/PNAd, alpha4betal integrin/VCAM-1, and LFA-1 adhesion pathways. J Exp Med (2003) 197:1255-67. doi:10.1084/jem.20010685

20. Campbell DJ, Butcher EC. Rapid acquisition of tissue-specific homing phenotypes by $\mathrm{CD} 4(+) \mathrm{T}$ cells activated in cutaneous or mucosal lymphoid tissues. J Exp Med (2002) 195:135-41. doi:10. 1084/jem.20011502

21. Mora JR, Bono MR, Manjunath $\mathrm{N}$, Weninger W, Cavanagh LL, Rosemblatt $M$, et al. Selective imprinting of gut-homing $\mathrm{T}$ cells by Peyer's patch dendritic cells. Nature (2003) 424:88-93. doi:10. 1038/nature01726

22. Mora JR, Cheng G, Picarella D, Briskin M, Buchanan N, von Andrian UH. Reciprocal and dynamic control of CD8 $\mathrm{T}$ cell homing by dendritic cells from skin- and gut-associated lymphoid tissues. J Exp Med (2005) 201:30316. doi:10.1084/jem.20041645

23. Dudda JC, Lembo A, Bachtanian E, Huehn J, Siewert C, Hamann A, et al. Dendritic cells govern induction and reprogramming of polarized tissue-selective homing receptor patterns of $\mathrm{T}$ cells: important roles for soluble factors and tissue microenvironments. Eur J Immunol (2005) 35:1056-65. doi:10.1002/eji. 200425817 
24. Iwata M, Hirakiyama A, Eshima Y, Kagechika H, Kato C, Song SY. Retinoic acid imprints gut-homing specificity on $\mathrm{T}$ cells. Immunity (2004) 21:527-38. doi:10.1016/j. immuni.2004.08.011

25. Yokota A, Takeuchi H, Maeda N, Ohoka Y, Kato C, Song S-Y, et al. GM-CSF and IL-4 synergistically trigger dendritic cells to acquire retinoic acid-producing capacity. Int Immunol (2009) 21:361-77. doi:10.1093/intimm/dxp003

26. Johansson-Lindbom B, Agace WW. Generation of gut-homing T cells and their localization to the small intestinal mucosa. Immunol Rev (2007) 215:226-42. doi:10. 1111/j.1600-065X.2006.00482.x

27. Sigmundsdottir H, Pan J, Debes GF, Alt C, Habtezion A, Soler D, et al. DCs metabolize sunlightinduced vitamin D3 to "program" $\mathrm{T}$ cell attraction to the epidermal chemokine CCL27. Nat Immunol (2007) 8:285-93. doi:10. 1038/ni1433

28. Lim YC, Xie H, Come CE, Alexander SI, Grusby MJ, Lichtman AH, et al. IL-12, STAT4dependent up-regulation of CD4(+) T cell core 2 beta-1,6-nacetylglucosaminyltransferase, an enzyme essential for biosynthesis of P-selectin ligands. J Immunol (2001) 1950(167):4476-84.

29. Carlow DA, Williams MJ, Ziltener HJ. Inducing P-selectin ligand formation in CD8 T cells: IL-2 and IL-12 are active in vitro but not required in vivo. J Immunol (2005) 1950(174):3959-66.

30. Iwasaki M, Mukai T, Gao P, Park WR, Nakajima C, Tomura M, et al. A critical role for IL-12 in CCR5 induction on $\mathrm{T}$ cell receptor-triggered mouse CD4(+) and CD8(+) T cells. Eur J Immunol (2001) 31:2411-20. doi:10.1002/ 1521-4141(200108)31:8<2411: :AID-IMMU2411>3.0.CO;2-Y

31. Nakajima C, Mukai T, Yamaguchi N, Morimoto Y, Park WR, Iwasaki $M$, et al. Induction of the chemokine receptor CXCR3 on TCR-stimulated T cells: dependence on the release from persistent TCR-triggering and requirement for IFN-gamma stimulation. Eur J Immunol (2002) 32:1792-801. doi:10.1002/15214141(200206)32:6<1792::AIDIMMU1792>3.0.CO;2-0

32. Sheasley-O'Neill SL, Brinkman CC, Ferguson AR, Dispenza MC, Engelhard VH. Dendritic cell immunization route determines integrin expression and lymphoid and nonlymphoid tissue distribution of CD8 T cells. I Immunol (2007) 178:1512-22.

33. Ferguson AR, Engelhard VH. CD8 $\mathrm{T}$ cells activated in distinct lymphoid organs differentially express adhesion proteins and coexpress multiple chemokine receptors. J Immunol (2010) 184:4079-86. doi: 10.4049/jimmunol.0901903

34. Brinkman CC, Sheasley-O’Neill SL, Ferguson AR, Engelhard VH. Activated CD8 T cells redistribute to antigen-free lymph nodes and exhibit effector and memory characteristics. J Immunol (2008) 181:1814-24.

35. Berlin C, Bargatze RF, Campbell JJ, von Andrian UH, Szabo MC, Hasslen SR, et al. Alpha 4 integrins mediate lymphocyte attachment and rolling under physiologic flow. Cell (1995) 80:413-22. doi:10. 1016/0092-8674(95)90491-3

36. Butcher EC, Picker LJ. Lymphocyte homing and homeostasis. Science (1996) 272:60-6. doi:10.1126/ science.272.5258.60

37. Milstone DS, Fukumura D, Padgett RC, O'Donnell PE, Davis VM, Benavidez OJ, et al. Mice lacking E-selectin show normal numbers of rolling leukocytes but reduced leukocyte stable arrest on cytokine-activated microvascular endothelium. Microcirculation (1998) 5:153-71. doi:10.1111/ j.1549-8719.1998.tb00065.x

38. Siegelman MH, Stanescu D, Estess P. The CD44-initiated pathway of T-cell extravasation uses VLA-4 but not LFA-1 for firm adhesion. J Clin Invest (2000) 105:683-91. doi:10.1172/JCI8692

39. Dudda JC, Simon JC, Martin S. Dendritic cell immunization route determines CD8+ T cell trafficking to inflamed skin: role for tissue microenvironment and dendritic cells in establishment of $\mathrm{T}$ cellhoming subsets. J Immunol (2004) 172:857-63.

40. Mullins DW, Sheasley SL, Ream RM, Bullock TN, Fu YX, Engelhard VH. Route of immunization with peptide-pulsed dendritic cells controls the distribution of memory and effector $\mathrm{T}$ cells in lymphoid tissues and determines the pattern of regional tumor control. J Exp Med (2003) 198:1023-34. doi:10.1084/jem.20021348

41. Rivino L, Messi M, Jarrossay D, Lanzavecchia A, Sallusto F, Geginat J. Chemokine receptor expression identifies pre-T helper (Th) 1 , PreTh2, and nonpolarized cells among human CD4+ central memory $\mathrm{T}$ cells. J Exp Med (2004) 200:72535. doi:10.1084/jem.20040774

42. Duhen T, Geiger R, Jarrossay D Lanzavecchia A, Sallusto F. Production of interleukin 22 but not interleukin 17 by a subset of human skin-homing memory T cells. Nat Immunol (2009) 10:857-63. doi: 10.1038/ni.1767

43. Olson TS, Ley K. Chemokines and chemokine receptors in leukocyte trafficking. Am J Physio Regul Integr Comp Physiol (2002) 283:R7-28.

44. Liu L, Fuhlbrigge RC, Karibian K, Tian T, Kupper TS. Dynamic programming of CD8+ T cell trafficking after live viral immunization. Immunity (2006) 25:511-20. doi: 10.1016/j.immuni.2006.06.019

45. Wagner N, Lohler J, Tedder TF, Rajewsky K, Muller W, Steeber DA. L-selectin and beta7 integrin synergistically mediate lymphocyte migration to mesenteric lymph nodes. Eur J Immunol (1998) 28:3832-9. doi:10.1002/(SICI) 1521-4141(199811)28:11<3832: :AID-IMMU3832>3.0.CO;2-J

46. Brinkman CC, Rouhani SJ Srinivasan N, Engelhard VH. Peripheral tissue homing receptors enable $\mathrm{T}$ cell entry into lymph nodes and affect the anatomical distribution of memory cells. J Immunol (2013). doi:10.4049/jimmunol.1300651

47. Guarda G, Hons M, Soriano SF, Huang AY, Polley R, MartinFontecha A, et al. L-selectinnegative CCR7- effector and memory CD8+ $\mathrm{T}$ cells enter reactive lymph nodes and kill dendritic cells. Nat Immunol (2007) 8:74352. doi:10.1038/ni1469

48. Martin-Fontecha A, Baumjohann D, Guarda G, Reboldi A, Hons M, Lanzavecchia A, et al. CD40L+ CD4+ memory $\mathrm{T}$ cells migrate in a CD62P-dependent fashion into reactive lymph nodes and license dendritic cells for $\mathrm{T}$ cell priming. J Exp Med (2008) 205:2561-74. doi:10.1084/jem.20081212

49. Sallusto F, Lenig D, Forster R, Lipp M, Lanzavecchia A. Two subsets of memory $\mathrm{T}$ lymphocytes with distinct homing potentials and effector functions. Nature (1999) 401:708-12. doi:10.1038/44385

50. Masopust D, Vezys V, Marzo AL, Lefrancois L. Preferential localization of effector memory cells in nonlymphoid tissue. Science (2001) 291:2413-7. doi:10.1126/ science. 1058867

51. Mora JR, von Andrian UH. T-cell homing specificity and plasticity: new concepts and future challenges. Trends Immunol (2006) 27:235-43. doi:10.1016/j.it.2006. 03.007

52. Masopust D, Picker LJ. Hidden memories: frontline memory $\mathrm{T}$ cells and early pathogen interception. J Immunol (2012) 188:58117. doi:10.4049/jimmunol.1102695

53. Bevan MJ. Memory T cells as an occupying force. Eur J Immunol (2011) 41:1192-5. doi:10.1002/eji. 201041377

54. Gebhardt T, Whitney PG, Zaid A, Mackay LK, Brooks AG, Heath WR, et al. Different patterns of peripheral migration by memory CD4(+) and CD8(+) T cells. Nature (2011) 477:216-9. doi:10. 1038/nature10339

55. Masopust D, Choo D, Vezys V, Wherry EJ, Duraiswamy J, Akondy $\mathrm{R}$, et al. Dynamic T cell migration program provides resident memory within intestinal epithelium. $J$ Exp Med (2010) 207:553-64. doi: 10.1084/jem.20090858

56. Hogan RJ, Usherwood EJ, Zhong W, Roberts AA, Dutton RW, Harmsen AG, et al. Activated antigenspecific CD8+ $\mathrm{T}$ cells persist in the lungs following recovery from respiratory virus infections. $J$ Immunol (2001) 166:1813-22.

57. Klonowski KD, Williams KJ, Marzo AL, Blair DA, Lingenheld EG, Lefrancois L. Dynamics of blood-borne CD8 memory $\mathrm{T}$ cell migration in vivo. Immunity (2004) 20:551-62. doi:10.1016/ S1074-7613(04)00103-7

58. Masopust D, Vezys V, Usherwood EJ, Cauley LS, Olson S, Marzo $\mathrm{AL}$, et al. Activated primary and memory CD8 $\mathrm{T}$ cells migrate to nonlymphoid tissues regardless of site of activation or tissue of origin. J Immunol (2004) 172:4875-82.

59. Campbell JJ, Murphy KE, Kunkel EJ, Brightling CE, Soler D, Shen Z, et al. CCR7 expression and memory $\mathrm{T}$ cell diversity in humans. $J$ Immunol (2001) 166:877-84.

60. Jennrich S, Ratsch BA, Hamann A, Syrbe U. Long-term commitment to inflammation-seeking homing in CD4+ effector cells. J Immunol (2007) 178:8073-80.

61. Williams MB, Butcher EC. Homing of naive and memory $\mathrm{T}$ lymphocyte subsets to Peyer's patches, lymph nodes, and spleen. J Immunol (1997) 159:1746-52.

62. Clark RA, Chong B, Mirchandani N, Brinster NK, Yamanaka K, Dowgiert RK, et al. The vast majority of CLA $+\mathrm{T}$ cells are resident 
in normal skin. J Immunol (2006) 176:4431-9.

63. Wherry EJ, Teichgraber V, Becker TC, Masopust D, Kaech SM, Antia R, et al. Lineage relationship and protective immunity of memory CD8 T cell subsets. Nat Immunol (2003) 4:225-34. doi:10. 1038/ni889

64. Marzo AL, Klonowski KD, Le BA, Borrow P, Tough DF, Lefrancois $\mathrm{L}$. Initial $\mathrm{T}$ cell frequency dictates memory $\mathrm{CD} 8+\mathrm{T}$ cell lineage commitment. Nat Immunol (2005) 6:793-9. doi:10.1038/ni1227

65. Unsoeld H, Pircher H. Complex memory T-cell phenotypes revealed by coexpression of CD62L and CCR7. J Virol (2005) 79:4510-3. doi:10.1128/JVI.79.7. 4510-4513.2005

66. Debes GF, Arnold CN, Young AJ, Krautwald S, Lipp M, Hay JB, et al. Chemokine receptor CCR7 required for $\mathrm{T}$ lymphocyte exit from peripheral tissues. Nat Immunol (2005) 6:889-94. doi:10. 1038/ni1238

67. Bromley SK, Thomas SY, Luster AD. Chemokine receptor CCR7 guides $\mathrm{T}$ cell exit from peripheral tissues and entry into afferent lymphatics. Nat Immunol (2005) 6:895-901. doi:10.1038/ni1240

68. Bromley SK, Yan S, Tomura M, Kanagawa O, Luster AD. Recirculating memory $\mathrm{T}$ cells are a unique subset of $\mathrm{CD} 4+\mathrm{T}$ cells with a distinct phenotype and migratory pattern. $J$ Immunol (2013) 190:970-6. doi:10.4049/ jimmunol.1202805

69. Vesely M, Kershaw M, Schreiber R, Smyth M. Natural innate and adaptive immunity to cancer. Annu Rev Immunol (2011) 29:235-71. doi:10.1146/annurevimmunol-031210-101324

70. Fridman WH, Pagès F, SautèsFridman C, Galon J. The immune contexture in human tumours: impact on clinical outcome. Nat Rev Cancer (2012) 12:298-306. doi:10.1038/nrc3245

71. Galon J, Costes A, Sanchez-Cabo F, Kirilovsky A, Mlecnik B, LagorcePages C, et al. Type, density, and location of immune cells within human colorectal tumors predict clinical outcome. Science (2006) 313:1960-4. doi:10.1126/science. 1129139

72. Erdag G, Schaefer JT, Smolkin ME, Deacon DH, Shea SM, Dengel LT, et al. Immunotype and immunohistologic characteristics of tumor-infiltrating immune cells are associated with clinical outcome in metastatic melanoma. Cancer Res (2012) 72:1070-80. doi:10.1158/0008-5472.CAN-113218

73. Buckanovich RJ, Facciabene A, Kim S, Benencia F, Sasaroli D, Balint $\mathrm{K}$, et al. Endothelin B receptor mediates the endothelial barrier to $\mathrm{T}$ cell homing to tumors and disables immune therapy. Nat Med (2008) 14:28-36. doi: $10.1038 / \mathrm{nm} 1699$

74. Blank C, Brown I, Kacha AK, Markiewicz MA, Gajewski TF. ICAM-1 contributes to but is not essential for tumor antigen cross-priming and CD8+ $\mathrm{T}$ cellmediated tumor rejection in vivo. J Immunol (2005) 174:3416-20.

75. Hensbergen PJ, Wijnands PG, Schreurs MW, Scheper RJ, Willemze R, Tensen CP. The CXCR3 targeting chemokine CXCL11 has potent antitumor activity in vivo involving attraction of CD8+ T lymphocytes but not inhibition of angiogenesis. J Immunother (1991) (2005) 28:343-51. doi:10.1097/01.cji. 0000165355.26795 .27

76. Kunz M, Toksoy A, Goebeler M, Engelhardt E, Bröcker E, Gillitzer R. Strong expression of the lymphoattractant $\mathrm{C}-\mathrm{X}-\mathrm{C}$ chemokine Mig is associated with heavy infiltration of $\mathrm{T}$ cells in human malignant melanoma. J Pathol (1999) 189:552-8. doi:10.1002/(SICI) 1096-9896(199912) 189:4<552: :AID-PATH469>3.0.CO;2-I

77. Zhang T, Somasundaram R, Berencsi K, Caputo L, Gimotty P, Rani P, et al. Migration of cytotoxic $\mathrm{T}$ lymphocytes toward melanoma cells in three-dimensional organotypic culture is dependent on CCL2 and CCR4. Eur J Immunol (2006) 36:457-67. doi:10.1002/eji.200526208

78. Musha H, Ohtani H, Mizoi T, Kinouchi M, Nakayama T, Shiiba $K$, et al. Selective infiltration of CCR5(+)CXCR3(+) T lymphocytes in human colorectal carcinoma. Int J Cancer (2005) 116:949-56. doi:10.1002/ijc.21135

79. Fisher DT, Chen Q, Skitzki JJ, Muhitch JB, Zhou L, Appenheimer $\mathrm{MM}$, et al. IL-6 trans-signaling licenses mouse and human tumor microvascular gateways for trafficking of cytotoxic $\mathrm{T}$ cells. J Clin Invest (2011) 121:3846-59. doi:10. 1172/JCI44952

80. Moran CJ, Arenberg DA, Huang C-C, Giordano TJ, Thomas DG, Misek DE, et al. RANTES expression is a predictor of survival in stage I lung adenocarcinoma. Clin Cancer Res (2002) 8:3803-12.

81. Niwa Y, Akamatsu H, Niwa $H$, Sumi H, Ozaki Y, Abe A. Correlation of tissue and plasma RANTES levels with disease course in patients with breast or cervical cancer. Clin Cancer Res (2001) 7:285-9.

82. Weishaupt C, Munoz KN, Buzney E, Kupper TS, Fuhlbrigge RC. T-cell distribution and adhesion receptor expression in metastatic melanoma. Clin Cancer Res (2007) 13:2549-56. doi:10.1158/ 1078-0432.CCR-06-2450

83. Clark RA, Huang SJ, Murphy GF, Mollet IG, Hijnen D, Muthukuru $M$, et al. Human squamous cell carcinomas evade the immune response by down-regulation of vascular E-selectin and recruitment of regulatory $\mathrm{T}$ cells. $J$ Exp Med (2008) 205:2221-34. doi:10. 1084/jem.20071190

84. Dengel LT, Norrod AG, Gregory BL, Clancy-Thompson E, Burdick MD, Strieter RM, et al. Interferons induce CXCR3cognate chemokine production by human metastatic melanoma. J Immunother (1991) (2010) 33:965-74. doi:10.1097/CJI. 0b013e3181fb045d

85. Wang L, Fan J, Thompson LF, Zhang Y, Shin T, Curiel TJ, et al. CD73 has distinct roles in nonhematopoietic and hematopoietic cells to promote tumor growth in mice. $J$ Clin Invest (2011) 121:2371-82. doi:10.1172/ JCI45559

86. Dirkx AEM, Oude Egbrink MG, Kuijpers MJ, van der Niet ST, Heijnen VV, Bouma-ter Steege JC, et al. Tumor angiogenesis modulates leukocyte-vessel wall interactions in vivo by reducing endothelial adhesion molecule expression. Cancer Res (2003) 63:2322-9.

87. Griffith KD, Read EJ, Carrasquillo JA, Carter CS, Yang JC, Fisher $\mathrm{B}$, et al. In vivo distribution of adoptively transferred indium111-labeled tumor infiltrating lymphocytes and peripheral blood lymphocytes in patients with metastatic melanoma. I Natl Cancer Inst (1989) 81:1709-17. doi:10.1093/jnci/81.22.1709

88. Fisher B, Packard BS, Read EJ, Carrasquillo JA, Carter CS, Topalian SL, et al. Tumor localization of adoptively transferred indium-111 labeled tumor infiltrating lymphocytes in patients with metastatic melanoma. J Clin Oncol (1989) 7:250-61.
89. Economou JS, Belldegrun AS, Glaspy J, Toloza EM, Figlin R, Hobbs J, et al. In vivo trafficking of adoptively transferred interleukin2 expanded tumor-infiltrating lymphocytes and peripheral blood lymphocytes. Results of a double gene marking trial. $J$ Clin Invest (1996) 97:515-21. doi:10.1172/JCI118443

90. Kershaw MH, Westwood JA, Parker LL, Wang G, Eshhar Z, Mavroukakis SA, et al. A phase I study on adoptive immunotherapy using gene-modified $\mathrm{T}$ cells for ovarian cancer. Clin Cancer Res (2006) 12:6106-15. doi:10.1158/ 1078-0432.CCR-06-1183

91. Matsumura S, Wang B, Kawashima $\mathrm{N}$, Braunstein S, Badura $\mathrm{M}$, Cameron TO, et al. Radiationinduced CXCL16 release by breast cancer cells attracts effector T cells. J Immunol (2008) 181:3099-107.

92. Thompson ED, Enriquez HL, Fu Y-X, Engelhard VH. Tumor masses support naive $\mathrm{T}$ cell infiltration, activation, and differentiation into effectors. $J$ Exp Med (2010) 207:1791-804. doi:10. 1084/jem.20092454

93. Rosen SD. Ligands for L-selectin: homing, inflammation, and beyond. Annu Rev Immunol (2004) 22:129-56. doi:10.1146/annurev. immunol.21.090501.080131

94. Gräbner R, Lötzer K, Döpping S, Hildner M, Radke D, Beer M, et al. Lymphotoxin $\beta$ receptor signaling promotes tertiary lymphoid organogenesis in the aorta adventitia of aged ApoE-/- mice. J Exp Med (2009) 206:233-48. doi:10. 1084/jem.20080752

95. Drayton DL, Liao S, Mounzer $\mathrm{RH}$, Ruddle NH. Lymphoid organ development: from ontogeny to neogenesis. Nat Immunol (2006) 7:344-53. doi:10.1038/ni1330

96. Martinet L, Garrido I, Filleron $\mathrm{T}$, Le Guellec S, Bellard E, Fournie J-J, et al. Human solid tumors contain high endothelial venules: association with T- and B-lymphocyte infiltration and favorable prognosis in breast cancer. Cancer Res (2011) 71:5678-87. doi:10.1158/00085472.CAN-11-0431

97. Messina JL, Fenstermacher DA, Eschrich S, Qu X, Berglund AE, Lloyd MC, et al. 12-Chemokine gene signature identifies lymph node-like structures in melanoma: potential for patient selection for immunotherapy? Sci Rep (2012) 2:765. doi:10.1038/srep00765 
98. Coppola D, Nebozhyn M, Khalil F, Dai H, Yeatman T, Loboda A, et al. Unique ectopic lymph node-like structures present in human primary colorectal carcinoma are identified by immune gene array profiling. Am J Pathol (2011) 179:37-45. doi:10.1016/j. ajpath.2011.03.007

99. Bergomas F, Grizzi F, Doni A, Pesce S, Laghi L, Allavena $P$, et al. Tertiary intratumor lymphoid tissue in colo-rectal cancer. Cancers (2011) 4:1-10. doi:10.3390/ cancers4010001

100. Browning JL, Allaire N, NgamEk A, Notidis E, Hunt J, Perrin $\mathrm{S}$, et al. Lymphotoxin-beta receptor signaling is required for the homeostatic control of HEV differentiation and function. Immunity (2005) 23:539-50. doi:10.1016/j. immuni.2005.10.002

101. Gatumu MK, Skarstein K, Papandile A, Browning JL, Fava RA, Bolstad A. Blockade of lymphotoxin-beta receptor signaling reduces aspects of Sjögren syndrome in salivary glands of non-obese diabetic mice. Arthritis Res Ther (2009) 11:R24. doi:10.1186/ar2617

102. Motallebzadeh R, Rehakova S, Conlon TM, Win TS, Callaghan CJ, Goddard M, et al. Blocking lymphotoxin signaling abrogates the development of ectopic lymphoid tissue within cardiac allografts and inhibits effector antibody responses. FASEB J (2012) 26:5162. doi:10.1096/fj.11-186973

103. Kratz A, Campos-Neto A, Hanson MS, Ruddle NH. Chronic inflammation caused by lymphotoxin is lymphoid neogenesis. J Exp Med (1996) 183:1461-72. doi:10.1084/ jem.183.4.1461

104. Cuff CA, Sacca R, Ruddle NH. Differential induction of adhesion molecule and chemokine expression by $\mathrm{LT} \alpha 3$ and $\mathrm{LT} \alpha \beta$ in inflammation elucidates potential mechanisms of mesenteric and peripheral lymph node development. J Immunol (1999) 162:596572.

105. Drayton DL, Ying X, Lee J, Lesslauer W, Ruddle NH. Ectopic LT $\alpha \beta$ directs lymphoid organ neogenesis with concomitant expression of peripheral node addressin and a HEV-restricted sulfotransferase. J Exp Med (2003) 197:1153-63. doi:10.1084/jem.20021761

106. Yu P, Lee Y, Liu W, Chin RK, Wang J, Wang Y, et al. Priming of naive T cells inside tumors leads to eradication of established tumors. Nat Immunol (2004) 5:141-9. doi:10. 1038/ni1029

Conflict of Interest Statement: The authors declare that the research was conducted in the absence of any commercial or financial relationships that could be construed as a potential conflict of interest.
Received: 07 May 2013; paper pending published: 05 June 2013; accepted: 03 August 2013; published online: 19 August 2013.

Citation: Brinkman CC, Peske JD and Engelhard VH (2013) Peripheral tissue homing receptor control of naïve, effector, and memory CD8 T cell localization in lymphoid and non-lymphoid tissues. Front. Immunol. 4:241. doi: 10.3389/fimmu.2013.00241

This article was submitted to Frontiers in Immunological Memory, a specialty of Frontiers in Immunology.

Copyright (C) 2013 Brinkman, Peske and Engelhard. This is an open-access article distributed under the terms of the Creative Commons Attribution License (CC $B Y)$. The use, distribution or reproduction in other forums is permitted, provided the original author(s) or licensor are credited and that the original publication in this journal is cited, in accordance with accepted academic practice. No use, distribution or reproduction is permitted which does not comply with these terms. 